\title{
RESIDUES OF CHLORPYRIFOS AND PROFENOFOS ON GREEN BEAN (Phaseolus vulgaris. L) AND SQUASH (Cucurbita pepo, L.) FRUITS AND THEIR SIDE EFFECT ON SOME QUALITY PROPERTIES \\ Reham M.AbdEI-Fatah*;A.A.Saleh*;Laila R.A.Elgohary* and Salwa E.Negm* \\ *Insecticide Dept., Faculty of Agriculture, Mansoura University, Egypt
}

\begin{abstract}
The residue levels of the two organophosphorus insecticides, Chlorpyrifos and Profenofos in fruits of green bean and squash in relation to their side effect on some internal quality properties were studied. The results showed that 10,14 and 7,14 days after application on green bean and squash is enough to reduce the Chlorpyrifos and Profenofos residues, respectively below the maximum residue limits (MRL). However, Chlorpyrifos appared to have relatively longer persistence with $t_{1 / 2}$ of 2.88 and 1.50 days than Profenofos with 1.20 and 0.85 days on green bean and squash fruits, respectively. As for the internal quality parameters of green bean, Chlorpyrifos treatment was significantly decreased the total soluble sugars, \% acidity, ascorbic acid (vitamin C), total nitrogen content, crude protein, total soluble solids (T.S.S.), $\beta$ carotene and total crude fats content. The Profenofos treatment was significantly decreased the total soluble sugars, $\%$ acidity, total soluble solids (T.S.S.), $\beta$-carotene and total crude fats content while it was not significantly decreased ascorbic acid (vitamin C), total nitrogen content and crude protein content. Both insecticide residues significantly decreased the total soluble sugars, \% acidity, ascorbic acid (vitamin $\mathrm{C}$ ), total nitrogen content, crude protein, total soluble solids (T.S.S.), $\beta$-carotene and total crude fats content in squash fruit.
\end{abstract}

Keywords: Green bean, Squash, Chlorpyrifos, Profenofos, quality, residues.

\section{INTRODUCTION}

Insecticides occupy a unique position among the many hazardous chemicals that man and animals encounter daily. Insecticides are intentionally introduced into the environment to enhance agricultural production, to reduce pest damage on crops and to control disease vectors.

The common bean plant (Phaseolus vulgaris. L), is one of the most important economic leguminous field crops that people prefer it as a source of protein, it is the world's third most important major food leguminous. Squash (Cucurbita pepo L.) is one of the most popular vegetable crops grown in Egypt that is grown in more than one season (Shehata et al., 2009). In this respect, the protection of green bean and Squash crops from the attacking of pests is considered as a key factor for the mass production of fruits. However there are a wide range of pests including insects, fungi, bacteria, virus and acaros. Such pests are affecting significantly the quantity and quality of green bean and Squash production.

Generally two insecticides chloropyriphos and profenfos are officially approved in Egypt for use in vegetables with of 2 week approximately to control white fly,aphid and gross hopes. Chloropyriphos is an exceptionally 
well understood and widely studied molecule (Aspelin, 1997). More than 250 studies have been conducted examining the uses and impacts of this molecule on human health and the environment (Gibson, et al., 1998). The toxicity of chloropyriphos like other OP insecticides is attributed specifically to the inhibition of the enzyme acetylcholinesterase (Ecobichon, 1996). Chloropyriphos has been shown to be non-carcinogenic (Young, et al., 1990) and does not adversely affect reproduction (Breslin, et al., 1996). The use of this insecticide continues to increase both in domestic and agricultural application, a reflection of the safety of this agent relative to the other related compounds (Roy, et al., 1998). Nevertheless, recent studies indicate that spraying of chloropyriphos in the indoor environment may pose considerable risk to public health (Gurunathan, et al., 1998).

Generally the work presented here is an attempt to study the persistence of Chlorpyrifose and profenfos on and in green bean and Squash fruits and also their side effect of the two insecticides residues on some quality parameters of fruit.

\section{MATERIALS AND METHODS}

Insecticide used:

\begin{tabular}{|l|c|c|c|}
\hline Common name & Trade name & $\begin{array}{c}\text { Chemical } \\
\text { (IUPAC)name }\end{array}$ & $\begin{array}{c}\text { Field recommended } \\
\text { rate }\end{array}$ \\
\hline Chloropyrifos & Hoky $50 \%$ E.C. & $\begin{array}{c}\text { O, O-diethyl O-(3,5,6- } \\
\text { trichloro-2-pyridinyl) } \\
\text { phosphorothioate }\end{array}$ & $1 \mathrm{~L} / \mathrm{fed}$. \\
\hline Profenofos & actacron72\% E.C. & $\begin{array}{c}\text { O-(4-bromo-2- } \\
\text { chlorophenyl) O-ethyl- } \\
\text { S-propyl } \\
\text { Phosphorothioate }\end{array}$ & $0.75 \mathrm{~L} / \mathrm{fed}$. \\
\hline
\end{tabular}

Determine the persistence of Insecticides on and in green bean and Squash:

Green bean (Phaseolus vulgaris. L) and Squash (Cucurbita pepo, L.) were planted at Mansoura University Experimental Station, Dakahlia Governorate, Egypt, in Febrauray 22, 2014 for green bean and in June 4, 2014 for Squash.The field was subjected to normal agricultural practices. Three treatments were used including the two insecticides and the control (check). Three replicates $\left(42 \mathrm{~m}^{2}\right.$ each) were used / plot. Treatments were arranged in completely randomized blocks design. Spraying was applied with the recommended rate of spraying for two times; Marce 31 and April 23 of 2014 for green bean and once at July 5, 2014 for Squash. Samples were randomly collected from the different treatments at one hour, 1, 3, 5, 7, 10 and 14 days after application. Residues of two insecticides were determined by using gas liquid chromatography (GLC).

\section{Extraction and cleaning up:}

This method was carried out according to Bowman (1980) with slight modification. Fifty grams of each sample were macerated for 3 minutes with $100 \mathrm{ml}$ of acetone. The mixture was filtered on a Buchner funnel. The blender and funnel were washed with $30 \mathrm{ml}$ portion of the same solvent. The filtrate 
solution was then transferred to a $500 \mathrm{ml}$ separately funnel and partitioned with 50,50 and $50 \mathrm{ml}$-hexane, respectively. After shaking the funnel, the $\mathrm{n}$ hexane layer drawn off and dried by adding anhydrous sodium sulphate. The dried extract was concentrated by using rotary evaporator at $40^{\circ} \mathrm{C}$.

Samples extracts were cleaned-up and analyzed according to the procedure of Bowman and Leuck (1971). In this procedure, the column was prepared by adding $2 \mathrm{gm}$ of anhydrous sodium sulphate, $10 \mathrm{gm}$ of silica gel mixed with $1 \mathrm{gm}$ of activated charcoal and finally $2 \mathrm{gm}$ of anhydrous sodium sulphate was added at the top of column. The extracted sample was added on the column and eluted with $100 \mathrm{ml}$ of $20 \%$ acetone in $\mathrm{n}$-hexane. The eluted components were evaporated by using a rotary evaporator at $40^{\circ} \mathrm{C}$, and then the residue was dissolved in $10 \mathrm{ml}$ acetone and stored in a refrigerator until determined by GLC.

Chromatographic analysis:

The gas chromatograph used was a Hewlett Packard GC Model 6890 equipped with a flame photometric detector (FPD) with phosphorus filter. A fused silica capillary (PAS- 1701) , column containing 14\% cyanopropilsyloxane as stationary phase $(30 \mathrm{~m}$ length $\times 0.32 \mathrm{~mm}$ internal diameter (i.d) $\times 0.25$ um film thickness), was used for the separation in the GC.

GC operating conditions were the following: Injector and detector temperatures were $240^{\circ} \mathrm{C}$ and $250^{\circ} \mathrm{C}$; initial oven temperature, $200^{\circ} \mathrm{C}$ for 2 min, raised at $5^{\circ} \mathrm{C} / \mathrm{min}$. and then held at $240^{\circ} \mathrm{C}$ for $10 \mathrm{~min}$. The carrier gas was nitrogen at $3 \mathrm{ml} / \mathrm{min}$. and hydrogen and air were used for the combustion at 75 and $100 \mathrm{ml} / \mathrm{min}$, respectively. The retention time values were 2.2, 2.9 and 6.4 minutes for chlorpyrifos and profenofos, respectively.

Recovery studies:

A series of fortified samples were prepared extracted and cleaned-up according to the examined insecticides in order to evaluate the validation of the method. Samples of Green bean (Phaseolus vulgaris. L) and Squash (Cucurbita pepo, L.) were fortified by adding known volume of each insecticide standard solution ( 1 and $2 \mathrm{ppm}$ ). The efficiency of extraction and clean-up methods for fortified plant samples were evaluated for each insecticide. The recovery percentage of chlorpyrifos, and profenofos were calculated by the following equation:

$\%$ Recovery $=((\mu \mathrm{g})$ present $/(\mu \mathrm{g})$ added $) \times 100$

Spiked levels were 1.0 and $2.0 \mathrm{ppm}$. The obtained results were corrected according to the recovery rate.

Table (1) indicated the \% recovery of the tested insecticides from the spiked samples. Data that the average recovery percent ranged between $90.22-82.55 \%, 93.53-83.35 \%$ for Chlorpyrifos and Profenofos, respectively 
Table (1): Recovery rates of Chlorpyrifos and Profenofos at spiked levels 1.0 and $2.0 \mathrm{ppm}$ :

\begin{tabular}{|l|c|c|c|}
\hline \multirow{2}{*}{ Fruits } & \multicolumn{3}{|c|}{ Insecticides } \\
\cline { 2 - 4 } & $\begin{array}{c}\text { Spiked level } \\
(\mathbf{p p m})\end{array}$ & $\begin{array}{c}\text { Chlorpyrifos } \\
\text { \% Recovery }\end{array}$ & Profenofos \\
\hline \multirow{2}{*}{ Green bean } & 1.0 & 82.55 & 93.53 \\
\cline { 2 - 4 } & 2.0 & 82.65 & 84.54 \\
\hline \multirow{2}{*}{ Squash } & 1.0 & 90.22 & 83.35 \\
\cline { 2 - 4 } & 2.0 & 84.84 & 84.38 \\
\hline
\end{tabular}

Half life:

The half life period of residue ( $T 1 / 2)$ for each insecticide was calculated using the following equation (Moye et al., 1987).

Calculation of the residues:

The residues were calculated by applying the following equation Of (Möllhoff 1975).

Side effect of insecticides used on some quality parameters of fruit.

Analytical determination for the studied chemical quality parameters was made on treated and untreated fruit to evaluate the side effect of the tested insecticide residues on the quality of fruit. These chemical parameters included total soluble sugars were determined according to the method described by Sadasivam and Manickam, (1996), \% acidity was determined according to (A.O.A.C.; 1975), Ascorbic acid (vitamin C) was determined according to the method described by Mazumdar and Majumder, (2003) using titrimetric estimation with 2, 6 dicholoro phenol dye solution. Total nitrogen content was determined as described by Jones et al., (1991) Using Micro-kjeldahl apparatus, Crude protein was calculated by multiplying nitrogen percentage by the factor 5.75 , Total soluble solids (T.S.S.) were estimated using Galli 110 refractometer according to (A.O.A.C.; 1975.), $\beta$ carotene was determined by the method of Ben-Amotz and Avron (1983) andTotal crude fats were estimated according to (A.O.A.C. (1984)).

Statistical analysis:-

The obtained data were subjected to analysis of variance (ANOVA) by using "Genstat 11.1" (2008). The mean comparisons were performed by the least significant difference value (LSD) at $5 \%$ level of probability according to Gomez and Gomez. (1984).

\section{RESULTS AND DISCUSSION}

\section{I- Persistence of Chlorpyrifose and profenfos in and on Green bean and} Squash fruit:

Data in table (2) showed the residues of Chlorpyrifose and Profenfos in green bean and squash fruits.

\section{A- Chlorpyrifose residues:}

1- Green bean fruits:

The initial deposit of Chlorpyrifose was $1.8960 \mathrm{ppm}$ one hour after application then decreased to $1.7883,1.2104,0.5687,0.3126,0.0346$ and $0.0173 \mathrm{ppm}$ indicated the rate loss were $5.68,36.16,70.00,83.51,98.17$ and $99.09 \%$ after $1,3,5,7,10$ and 14 days respectively (table 2 ). The rate of 
decomposition $(K)$ was 0.24033 day $^{-1}$, the corresponding half life $\left(T^{1 / 2}\right)$ of Chlorpyrifose in green bean fruits was 2.8843 days. The data show that green bean fruits could be safely consumed after 10 days of application according to the recommended maximum residue limit (MRL) for Chlorpyrifose in green bean $(0.05 \mathrm{ppm})$. The maximum residue limits (MRL) of Chlorpyrifose was established in (European Union 2010) for green bean.

\section{2- Squash fruits:}

The initial deposit of Chlorpyrifose on and in squash was $8.3373 \mathrm{ppm}$ one hour after application then decreased to 5.7697, 3.4368, 1.2486, 0.0519, $0.0312,0.0198 \mathrm{ppm}$ indicating the rate of loss $30.80,58.78,85.02,99.38$, 99.62 and $99.76 \%$ after $1,3,5,7,10$ and 14 days respectively (table 2 ). The rate of decomposition $(\mathrm{K})$ was 0.45985 day $^{-1}$, the corresponding half life ( $\left.T^{1 / 2}\right)$ of Chlorpyrifose in squash fruits was 1.5074 days. The data show that squash fruits could be safely consumed after 7 days of application according to the recommended maximum residue limit (MRL) for Chlorpyrifose in squash (0.05 ppm). The maximum residue limits (MRL) of Chlorpyrifose was established in (European Union 2010).

Table (2): Residues of Chlorpyrifose and Profenofos in Green bean and Squash fruits:

\begin{tabular}{|c|c|c|c|c|c|c|c|c|}
\hline \multirow{3}{*}{$\begin{array}{l}\text { Time after } \\
\text { application } \\
\text { (days) }\end{array}$} & \multicolumn{4}{|c|}{ Green bean } & \multicolumn{4}{|c|}{ Squash } \\
\hline & \multicolumn{2}{|c|}{ Chlorpyrifose } & \multicolumn{2}{|c|}{ Profenofos } & \multicolumn{2}{|c|}{ Chlorpyrifose } & \multicolumn{2}{|c|}{ Profenofos } \\
\hline & $\begin{array}{c}\text { Residues } \\
\text { (ppm) }\end{array}$ & $\begin{array}{c}\% \\
\text { loss }\end{array}$ & $\begin{array}{c}\text { Residues } \\
\text { (ppm) }\end{array}$ & $\begin{array}{c}\% \\
\text { loss }\end{array}$ & $\begin{array}{c}\text { Residues } \\
\text { (ppm) }\end{array}$ & $\%$ loss & $\begin{array}{c}\text { Residues } \\
\text { (ppm) }\end{array}$ & $\begin{array}{c}\% \\
\text { loss }\end{array}$ \\
\hline Initial $^{*}$ & 1.8960 & 00.00 & 7.8526 & 00.00 & 8.3373 & 00.00 & 17.4393 & 00.00 \\
\hline 1 & 1.7883 & 5.68 & 4.2483 & 45.90 & 5.7697 & 30.80 & 5.966 & 65.79 \\
\hline 3 & 1.2104 & 36.16 & 0.776 & 90.12 & 3.4368 & 58.78 & 1.5943 & 90.86 \\
\hline 5 & 0.5686 & 70.00 & 0.7256 & 90.76 & 1.2486 & 85.02 & 0.3569 & 97.95 \\
\hline 7 & 0.3126 & 83.51 & 0.4505 & 94.26 & 0.0518 & 99.38 & 0.0300 & 99.83 \\
\hline 10 & 0.0346 & 98.17 & 0.0228 & 99.71 & 0.0312 & 99.62 & 0.0176 & 99.90 \\
\hline 14 & 0.0173 & 99.09 & 0.0019 & 99.97 & 0.0198 & 99.76 & 0.0031 & 99.98 \\
\hline $\mathrm{K}$ & \multicolumn{2}{|c|}{0.24033} & \multicolumn{2}{|c|}{0.5743} & \multicolumn{2}{|c|}{0.45985} & \multicolumn{2}{|c|}{0.8105} \\
\hline T $1 / 2$ (days) & \multicolumn{2}{|c|}{2.8843} & \multicolumn{2}{|c|}{1.2071} & \multicolumn{2}{|c|}{1.5074} & \multicolumn{2}{|c|}{0.8552} \\
\hline MRL(ppm) (EU 2010) & \multicolumn{2}{|c|}{0.05} & \multicolumn{2}{|c|}{0.01} & \multicolumn{2}{|c|}{0.05} & \multicolumn{2}{|c|}{0.01} \\
\hline PHI(days) & \multicolumn{2}{|c|}{10} & \multicolumn{2}{|c|}{14} & \multicolumn{2}{|c|}{7} & \multicolumn{2}{|c|}{14} \\
\hline
\end{tabular}

*: Samples were taken one hour after application.

$K=$ Rate of decomposition. $\quad T 1 / 2=$ Half life period (day).

$M R L=$ The maximum residue limits of chlorpyrifose was established in

$\mathrm{EU}=($ European Union 2010). $\mathrm{PHI}=$ Pre-harvest interval days after application.

In fact, the presente results are in same of many invegstigatiants, Sallam and El-Nabarawy (2001) reported that unwashed moloukhia leaves could be marketed safely after 15 days from spraying with Chlorpyrifose and its half life was 1.41 days. Mansoor-ul-Hassan et al. (2005) investigated residual persistence of chlorpyriphos residues on brinjal fruit after 3 hours, 3 days and 7 days after application. The residues on the three sampling periods (max-min) ranged from 0.075-0.039, 0.030-0.015 and 0.067-0.040 ppm, respectively. This leads to conclusion that it is safe to recommend brinjal fruit for human consumption after three days of spraying. Al-Eed and Mohammed (2006) determined the residues of Chlorpyrifos-ethyl on 
greenhouse tomato and pepper fruits. The data showed that the degradation was $8.2,0.2$ and $73.2 \%$ after one, three and seven days, respectively. Chlorpyrifos-ethyl residues on tomato or pepper fruits after 3 days represented more than ten folds of the maximum residue limits on vegetables $(50 \mu \mathrm{g} \mathrm{kg}-1)$. The data also showed that the half-life $t_{1 / 2}$ was 0.5 and 0.9 day for chlorpyrifos-ethyl on tomato and pepper, respectively. Chao et al. (2013) found that the the recoveries of chlorpyrifos in cabbage vegetable were 87.2$92.2 \%$ (RSD, 1.2-2.5). Lu et al. (2014) found that the half-lives of chlorpyrifos were 2.64 in pepper plants, 3.90 in asparagus lettuce, 3.92 in lettuce, 5.81 in brassica chinensis, 3.00 in eggplant plant, and 5.45 days in celery.

\section{B- Profenfos residues:}

\section{1- Green bean fruits:}

The initial deposit of Profenfos was $7.8527 \mathrm{ppm}$ one hour after then decreased to $4.2483,0.7760,0.7257,0.4505,0.0229$ and $0.0019 \mathrm{ppm}$ indicated the rate loss were 45.90, 90.12, 90.76, 94.26, 99.71 and $99.97 \%$ after $1,3,5,7,10$ and 14 days respectively(table 2). The rate of decomposition $(K)$ was 0.57427 day $^{-1}$, the corresponding half life $\left(T^{1 / 2}\right)$ of Profenfos in green bean fruits was 1.207 days. The data show that green bean fruits could be safely consumed after 14 days of application according to the recommended maximum residue limit (MRL) for Profenfos in green bean $(0.01 \mathrm{ppm})$. The maximum residue limits (MRL) of Profenfos was established in (European Union 2010) for green bean.

\section{2- Squash fruits:}

The initial deposit of Profenfos on and in squash was $17.4393 \mathrm{ppm}$ one hour after application then decreased to $5.9660,1.5944,0.3569,0.0300$, 0.0176 and $0.0031 \mathrm{ppm}$ indicated the rate loss were $65.79,90.86,97.95$, $99.83,99.90$ and $99.98 \%$ after $1,3,5,7,10$ and 14 days respectively(table 2). The rate of decomposition (K) was $0.8105 \mathrm{day}^{-1}$, the corresponding half life $\left(T \frac{1}{2}\right)$ of Profenfos in squash fruits was 0.8552 days. The data show that squash fruits could be safely consumed after 14 days of application according to the recommended maximum residue limit (MRL) for Profenfos in squash (0.01 ppm). The maximum residue limits (MRL) of Profenfos was established in (European Union 2010).

Similar results were obtained by Shahin et al. (1985), who treated soybean plants with profenofos, the initial deposit was $28.50 \mathrm{ppm}$ on and in the green pods, whereas residue half life was 2.35 days. Ramadan, (1991) The initial deposits of profenofos on and in unwashed tomato and okra fruits were 10.18 and $11.65 \mathrm{ppm}$, and this amounts were decreased to 0.04 and 0.025 after 15 days of spraying. Badawy et al. (1995) found that, the initial deposits of profenofos after one hour of application in unwashed tomato fruits was $3.20 \mathrm{ppm}$. Mohamed (1995) found that the initial deposits of profenofos on squash, cucumber and cabbage were 8.98, 7.39 and $15.47 \mathrm{ppm}$, these values decreased to $0.57,0.46$ and $1.59 \mathrm{ppm}$ after 7 days from application, also the half lives were $1.88,1.67$ and 1.80 days, respectively. Hegazy and Nasr (2003) found that the initial deposit of profenofos on and in moloukhia leaves after 1 hour of spraying was $114.6 \mathrm{ppm}$, this residues decreased to $1.56 \mathrm{ppm}$ after 10 days. 
El-Nabarawy (1992) found that, the total residues of profenofos was safely consumed at $7^{\text {th }}$ day after spraying on broad bean plants. Abdalla et al. (1993) found that green beans could be used safely for consumption after 11 days from spraying with profenofos and its half life was 1.6 days. Shiboob (1995) reported that, the tolerance level of profenofos on cucumber obtained after 12 days. Romeh (1999) reported that profenofos on and in unwashed green snap bean fruits was safely for consumption after 15 days of application, the median degradation time was 3 days. Sallam and ElNabarawy (2001) reported that unwashed moloukhia leaves could be marketed safely after 18 days from spraying with profenofos and its half life was 2.17 days. Shiboob (2001) found that the permissible time for profenofos was 10 days on sweet pepper fruit and 14 days on hot-pepper and eggplant fruits, the residues half lives were $1.74,1.83$ and 1.95 days, respectively. Mohamed et al. (2004) found that the consumable safety time of profenofos were 10 days on sweet pepper and 14 days on hot pepper and eggplant fruits. The corresponding half-lives (t1/2) were 1.84, 1.74 and 1.96 days. Aioub (2005) found that the initial deposit of profenofos in and on green leaves of cowpea plants was $18.52 \mathrm{mg} / \mathrm{kg}$ so it could be used after 7 days of spraying. Muhammad et al. (2010 found that the half life of profenofos on the cabbage crop was 2.11 days.

II- Side effect of insecticides used on Green bean (Phaseolus vulgaris. L)and Squash (Cucurbita pepo, L.) Fruits:-

The data in table (3) indicated that Chlorpyrifos treatment was significantly decreased the total soluble sugars, \% acidity, ascorbic acid (vitamin C), total nitrogen content, crude protein, total soluble solids (T.S.S.), $\beta$-carotene and total crude fats content in green bean fruits. The Profenofos treatment was significantly decreased the total soluble sugars, \% acidity, total soluble solids (T.S.S.), $\beta$-carotene and total crude fats content while it was not significantly decreased ascorbic acid (vitamin $\mathrm{C}$ ), total nitrogen content and crude protein content.

Table (3): Effect of Chlorpyrifose and Profenofos on some fruit quality parameters of treated Green bean (phaseolus vulgaris):

\begin{tabular}{|l|c|c|c|c|}
\hline \multirow{2}{*}{ Parameters } & \multicolumn{4}{|c|}{ Treatment } \\
\cline { 2 - 5 } & Chlorpyrifose & Profenofos & check & LSD5\% \\
\hline Total soluble sugars & 5.223 & 5.803 & 6.390 & 0.0953 \\
\hline$\%$ Acidity & 0.6833 & 0.7633 & 0.8267 & 0.05124 \\
\hline Ascorbic acid(mg/100g) & 25.83 & $26.77^{*}$ & 27.90 & 1.039 \\
\hline Total nitrogen & 3.233 & $3.503^{*}$ & 3.707 & 0.2193 \\
\hline Crude protein \% & 20.20 & $21.90^{*}$ & 23.17 & 1.392 \\
\hline Total soluble solids (T.S.S) & 7.087 & 7.230 & 7.720 & 0.2057 \\
\hline$\beta$-carotene (mg/100g) & 2.503 & 2.717 & 3.413 & 0.0916 \\
\hline Total fats \% & 1.413 & 1.630 & 1.920 & 0.0834 \\
\hline
\end{tabular}

*: not significantly different at $5 \%$ level of probability according to Gomez and Gomez. (1984). 
Results in table (4) indicated that chlorpyrifos and profenofos were significantly decreased the total soluble sugars, total acid, ascorbic acid, total nitrogen, crude protein, total soluble solids, $\beta$-carotene and total fats in squash fruit throughout the experiment. Profenfos caused reduction effect higher than other insecticide in treated fruit when compared with the control.

Table (4): Effect of Chlorpyrifose and Profenofos on some fruit quality parameters of treated squash (Cucurbita pepo, L.)

\begin{tabular}{|l|c|c|c|c|}
\hline \multirow{2}{*}{ Parameters } & \multicolumn{4}{|c|}{ Treatment } \\
\cline { 2 - 5 } & Chlorpyrifose & Profenofos & check & LSD5\% \\
\hline Total soluble sugars & 2.19 & 2.03 & 2.760 & 0.0822 \\
\hline \% Acidity & 0.58 & 0.59 & 0.7267 & 0.05886 \\
\hline Ascorbic acid(mg/100g) & 13.70 & 13.13 & 15.70 & 0.905 \\
\hline Total nitrogen & 1.23 & 1.14 & 1.4400 & 0.02048 \\
\hline Crude protein \% & 7.71 & 7.13 & 9.007 & 0.1230 \\
\hline Total soluble solids (T.S.S) & 6.28 & 6.12 & 6.797 & 0.0941 \\
\hline 及-carotene(mg/100g) & 4.59 & 4.27 & 5.340 & 0.1115 \\
\hline Total fats \% & 0.92 & 0.85 & 1.177 & 0.0894 \\
\hline \multirow{2}{*}{ * not significantly different at 5\% level of probability according to Gomez and Gomez. }
\end{tabular}

*: not significantly different at $\mathbf{5 \%}$ level of probability according to Gomez and Gomez. (1984).

It is well established that certain insecticides influence the chemical composition of the plants after they are applied. Othman et al. (1987) reported that dimethoate and methomyl residues had significant effects on ascorbic acid contents in tomato fruits. Dimethoate also showed significant effects on total soluble solids in tomato fruits. Habiba et al., (1992) reported that profenfos residues increased protein and ascorbic acid content in potatoes. Agrawal et al., (1993) found that fenthion reduced ascorbic acid contents in rice plants. Edrisha and Badr (1994) found that Pirimiphos-methyl and profenofos decreased the ascorbic acid content. Shallendra et al. (2013) found that the imidacloprid insecticide treatment decreased the ascorbic acid contents of potatoes but increased the total protein content. Ismail et al. (1993) found that profenofos increased T.S.S and acidity, but decreased the glucose, protein and ascorbic acid content of tomatoes. Radwan et al. (1995) reported that primiphos- methyl residue appeared to have significant adverse effects on the total soluble sugars and ascorbic acid content of tomato fruit and broad bean seeds. Radwan et al. (2001) reported that primiphos- methyl exhibited a significant increase on total soluble sugars and $\%$ acidity of grape berries, where as there was no effect on refractometric T.S.S. Radwan et al. (2004) reported that pirimiphos-methyl treatment significant increase the total soluble sugars, \% dry matter, total protein and $\beta$-carotene content in green pepper fruit. The profenofos treatment significantly decreased the total soluble sugars, \% dry matter and total protein and has no adverse effect on the $\%$ acidity, ascorbic acid and $\beta$ - carotene content. Both insecticide 
residues increased ascorbic acid content and decreased the total soluble sugars, \% acidity, T.S.S. in eggplant fruit. El-Shafey and EL-Akkad (1994) reported that Actellic induced depletion of the protein content in both shoots and roots of Phaseolus plant. Osman et al. (2006) reported that Chlorpyrifos increased significantly Protein content in cottonseeds.

From the previously mentioned results it could be said that the vegetables treatments could be safely consumed after few days but, it is necessary to research effect of compounds that reduce the negative effect on the fruit contains, and at the same time exerts excellent control against pests, especially on vegetables and has different mode of action.

\section{REFERENCES}

A.O.A.C. (1975) "Official methods of Analysis" Twelfth Ed. Published by the Association of Official Analytical chemists, Benjamin, France line station, Washington. Dc.

A.O.A.C. (1984) "Official methods of Analysis" $13^{\text {th }}$ Ed. Published by the Association of Official Analytical chemists, Washington. Dc. U.S.A

Abdallah, E. F.; E. A. Sammour; S. A. Abdallah and E. I. El-Said (1993): Persistence of some organophosphate insecticide residues on tomato and bean plants. Bull. Fac. Agric., Cairo Univ., 4 (2): 465-476.

Agrawal, S. B.; K. B. Singh and M. Agrawal (1993). Effect of an organophosphorus insecticide fenthion on pigment concentration and metabolic activities of rice plants. Bio. Sci. 63 (2). 189- 193.

Aioub, A. A. A. (2005): Residues of certain insecticides on and in cowpea plants and soil. Zagazig. J. Agric. Res., Vol. 32 No. (1): 267-278.

Al-Eed and A. Mohammed (2006). Determination of Pirimiphos-Methyl and Chlorpyrifos-Ethyl Residues on Tomato and Pepper Fruits Grown in Greenhouse. Journal of Applied Science. 6(4): 979-982.

Aspelin, A.L. (1997) Insecticide Industry Sales and Usage: 1994 and 1995 Market Estimates. Office of Insecticide Programs, US EPA 733-R-97002, Washington, DC.

Badawy, H.M.A.; F. Samara and A.A. Barakat (1995). Persistence of profenofos and pirimiphos-methyl in fresh tomato fruits and paste. J. Bull. Ent. Soc. Egypt, Econ. Ser., 14:2-9.

Ben-Amotz, A. B. and M. Avron.( 1983).On the Factors Which Determine Massive beta-Carotene Accumulation in the Halotolerant Alga Dunaliella bardawil. Plant. Physiol. 72:593-597.

Bowman, M.C. (1980). Analysis of organophosphorus insecticides. (C.F. Moye, H.A. (1980). Analysis of insecticide redisues. John Wiley, Sons, Inc. Chapter 7, PP. 263-332).

Bowman, M.C. and D.B. Leuck (1971). Determination and persistence of phoxim and its oxygen analog in forage corn and grass. J. Agric. Food Chem., 19(6):12151218. 
Breslin, W.J. ; A.B. Liberacki ; D.A. Dittenber; J.F. Quast (1996) Evaluation of the developmental and reproductive toxicity of chloropyrifos in the rat, Fundam. Appl. Toxicol. 29:119-130.

Chao Z.; J. Yan; F. J. She and Y. Hong (2013). Analysis of chlorpyrifos and chlorpyrifos-methyl residues in multi-environmental media by cloudpoint extraction and HPLC. Anal. Methods, 2013,5, 3089-3095.

Ecobichon, D.J. (1996) Toxic effects of insecticides, in: C.D. Klaassen (Ed.), Casarett and Doull's Toxicology, The Basic Science of Poisons, McGraw-Hill, New York, 643-689.

Edrisha, M. E. and S. T. Badr (1994) . Effect of some foliar fertilizers, insecticides and their mixtures on white fly Bemisia tabaci (Genn.) and their side effects on tomato fruits. Annals of Agricultural Science, Moshtohor. 32(3):1697-1706.

EI-Nabarawy, I.M. (1992). Assessment of profenofos, pirimiphos-ethyl and pirimiphosmethyl residues on and in broad bean pods. Egypt. J. Appl. Sci., 7(12):348353.

El-Shafey, A. M. S. and S.S. EL-Akkad, (1994). Metabolic and hormonal changes in Phaseolus vulgaris induced by treatment with the insecticide Actellic. J. Physiolo. , 18 (1). 127-146.

European Union. (2010). Maximum residue limits for insecticides.

GenStat Release 11.1 ( PC/Windows) Copyright 2008, VSN International Ltd., 5 waterhouse street, Hemel Hempstead HP11 ES, UK.

Gibson, J.E. ; R.K.D. Peterson and B.A. Shurdut (1998) Human exposure and risk from indoor use of chloropyriphos, Environ. Heal. Perspect. 106: 303-305.

Gomez, K. A. and A. A. Gomez (1984). Statistical Procedures For the Agriculture Research. John Wiley Sons, Int. Rice Res. Tnst. Book, 2 Ed.

Gurunathan, S.; Bukowski, J.; Lioy, P.J. (1998) Accumulation of chloropyrifos on residential surfaces and toys accessible to children. Environ. Heal. Perspect. $106: 9-16$.

Habiba, R.A.; H.M. Ali and S.M.M. Ismail (1992). Biochemical effects of profenofos residues in potatoes. J. Agric. Food Chem., 40(10):1852-1855.

Hegazy, M. E. A. and I. N. Nasr (2003): insecticide residues on and in moloukhia leaves grown under field conditions and the effect of processing on the residues. Bull. Fac. Agric., Cairo Univ., Vol. 54: 283292.

Ismail, S.M.; H.M. Ali and R.A. Habiba (1993). GC-ECD and GC-MS analysis of profenofos residues and biochemical effects in tomatoes and tomato products. J. Agric. Food Chem., 41:610-615.

Jones, J.; B. J. B. Wolf, and H. A. Mills, (1991). Plant analysis Handbook: A Practical Sampling, Preparation, Analysis, and Interpretative Guide. Micro-Macro Publishing, Athens, Ga.

Lu MengXiao; W. W. Jiang; J. L. Wang; Q. Jian; Y. Shen; X. J. Liu and X. Y. Yu (2014). Persistence and dissipation of chlorpyrifos in brassica chinensis, lettuce, celery, asparagus lettuce, eggplant, and pepper in a greenhouse. PLoS ONE. 9(6):e100556. 45 ref. 
Mansoor, U.H.; A. Farooq; S. Mohammed; F. I. Mazher and T. Muhammad (2005). Residual persistence of chlorpyriphos, imidachloprid and acephate in brinjal fruit. Pak. Entomol. 27 (1): 53-55.

Mazumdar, B. C. and K. Majumder (2003). Methods on Physic-Chemical Analysis of Fruits. Univ. Cokkege of Agric. Calcutta Univ., 108-109.

Mohamed, M.I.E. (1995). Evaluation for the persistence of some insecticide residues on vegetables. M.Sc. Thesis, Fac. Agric., Mansoura Univ.

Mohamed.A. R.; M.H. Shiboob; M.M. Abu-Elamayem and A. AbdelAal.(2004). Residual behaviour of profenofos on some field-grown vegetables and its removal using various washing solutions and household processing. Food and Chemical Toxicology. 43: 553-557.

Mollhof, E. (1975).Method for gas chromatographic determination of residue tokuthion and its Oxon in plants and soil samples. PflanzenschutzNachrichten Bayer, 28(3):382-387.

Moye, H.A.; M.H. Malagodi; J. Yoh; G.L. Leibee; C.C. Ku and P.G. Wislocki (1987). Residues of Avermectin $\mathrm{B}_{1}$ a rotational crops and soils following soil treatment with $\left({ }^{14} \mathrm{C}\right)$ Avermectin $\mathrm{B}_{1}$ a. Agric. Food Chem., 35:859-864.

Muhammad F. A.; A. H. Muhammad; P. Farzana; Y. Nikhat and A. S. Syed (2010). Determination of synthetic and bio-insecticide residues during Aphid (Myzus Persicae (Sulzer) control on Cabbage crop through High Performance Liquid Chromatography. Pakistan Entomologist. 32(2): 155-162.

Osman, G.A.; A.I. Mustafa and A. O. Abdelbagi, (2006).Effect of Chlorpyrifos on oil,protein,minerals and antinutritional factors of cotton seeds. J. Food Technology. Medwell Online, Faisalabad, Pakistan. 4(1)32-36.

Othman, M. A., G. F. Antonious; M. M. Khattab; A. Abdel-All and A. E. Khamis (1987), Residues of dimethioate and methomyl on tomato and cabbage in relation to their effect on quality-related properties. Environmental Toxicology and Chemistry, 6: 947-952.

Radwan, M.A.; M. H. Shiboob; A. Abdel-Aal and M. Abu-Elamayem. (2001). Residues of pirimiphos-methyl and fenitrothion in grapes, their effect on some quality properties and their dissipation during the removal and processing methods. J. Pest Cont. Environ. Sci. 9(3):89-107.

Radwan, M.A.; M.H. Shiboob; M.M. Abu-Elamayem and A. AbdelAal.(2004). Residues of Pirimiphos-methyl and profenofos on green pepper and eggplant fruits and their effect on some quality properties. Emir. J. Agric. Sci. 16(1):32-42.

Radwan, M.A.; M.M. Youssef; A.A. Aly; G.L. El-Henawy and A.E. Marei (1995). Residue levels of pirimiphos-methyl and chlorpyrifos-methyl on tomato and faba bean plants in relation to their impact on some internal quality parameters. Alex. Sci. Exch., 16(3):389-404.

Ramadan, R.A. (1991). Residues of profenofos and pirimiphos-methyl in tomato and okra fruits as influenced by certain technological processes. $4^{\text {th }}$ Nat. Cont. of Pests \& Dis. of Veg. \& Fruits in Egypt, 303-316.

Romeh, A.A.A. (1999). Decontamination of certain insecticides under different ecosystems. Ph.D. Thesis, Fac. of Agric., Zagazig Univ.

Roy, T.S. ; J.E. Andrews ; F.J. Seidler ; T.A. Slotkin (1998) Chloropyrifos elicits mitotic abnormalities and apoptosis in neuroepithelium of cultured rat embryos, Teratology 58 : 62-68. 
Sadasivam, S., and A. Manickam, (1996). Biochemical Methods, $2^{\text {nd }}$ Ed. New age inter. India.

Sallam, A.A.A. and I.M. El-Nabarawy (2001). Persistence of some insecticide residues on moloukhia leaves. J. Agric. Sci. Mansoura Univ., 26(3):1771-1778.

Shahin, A.; M.M. El-Sayed; M.A. El-Herrawio; M.M. Abou-Zahw and M.M. Almaz (1985). Persistence of profenofos residues on soybean plants. Proceeding of the $6^{\text {th }}$ Arab Insecticide Conf. Tanta Univ., 1:293-297.

Shallendra S. C.; A. Sanjeev and S. Anjana (2013). Effects of Imidacloprid insecticide Residue on biochemical parameters in potatoes and its estimation by HPLC. Asian J. Pharm Clin Res. 6(3): 114-117.

Shehata, S.M.; S.A. Saleh and H. Junge (2009). Response of Sexual Expression and Productivity of Squash Plants to Some Biofertilizer Treatments, ABITEP GMBH,http://www.abitep.de/content/pdf/e ffect fzb-24-squash-plants-egypt.pdf.

Shiboob, M.H.M. (1995). Biochemical studies on some bioactive compounds. M.Sc. Thesis, Fac. of Agric., Alex. Univ.

Shiboob, M.H.M. (2001). Studies on the analysis and side effect of certain insecticide residues. Ph.D. Thesis, Fac. of Agric., Alex. Univ.

Young, J.T.; J.R. Szabo; M. Grandjean (1990) Chloropyrifos: subchronic dietary toxicity/ oncogenicity study in Fischer-344 rat, Toxicologist 10: 344.

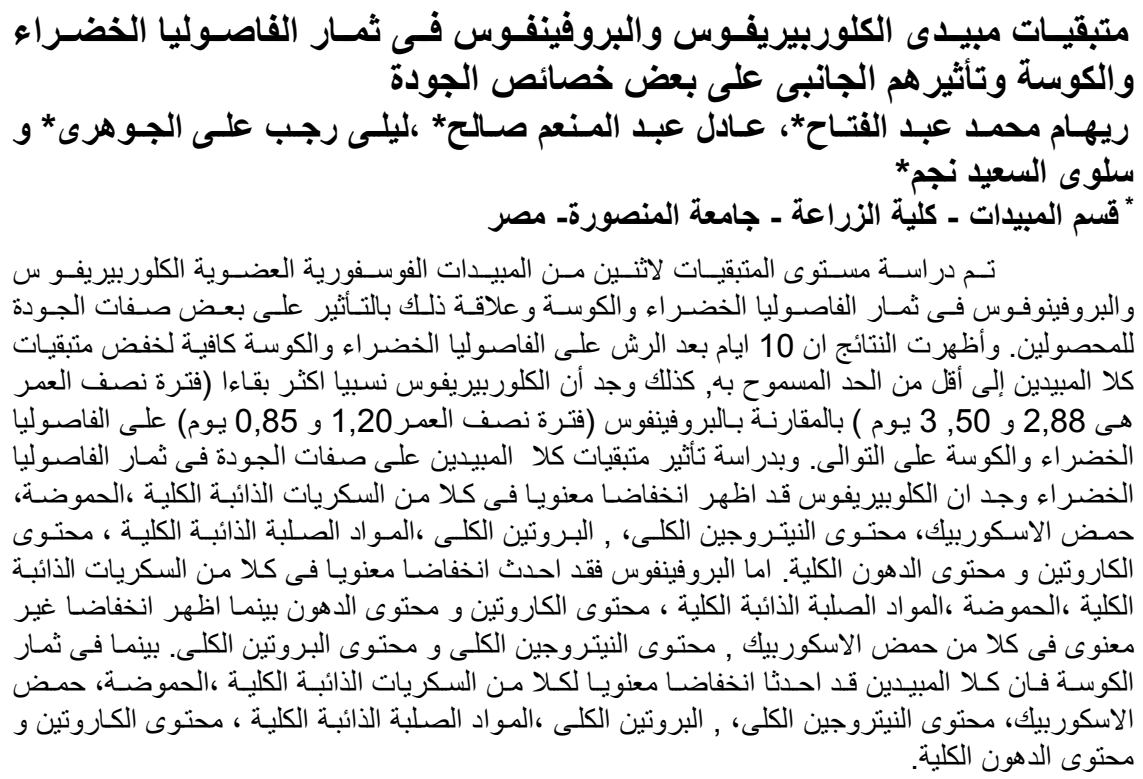

